\title{
PENGARUH GAME ONLINE TERHADAP MINAT UNTUK BELAJAR PESERTA DIDIK KELAS X DI MA AL HIDAYAH DEPOK
}

\author{
Ria Susanti Johan \\ Pendidikan Ekonomi/FIPPS, Unindra PGRI \\ ria.johan7@gmail.com
}

\begin{abstract}
Abstrak
Tujuan dari dlakukannya penelitian ini adalah untuk mengetahui seberapa besar pengaruh game online terhadap minat untuk belajar peserta didik kelas X. Hipotesis penelitian yang diuji meliputi: Adanya korelasi yang berkaitan antara game online dengan minat belajar sebesar 0,611. Dari hasil uji hipotesis (uji t) didapatkan hasil sebesar 5,060. Yakni Ha diterima dan Ho ditolak. Yang membuktikan terdapatnya pengaruh yang sangat signifikan antara game online dengan minat untuk belajar peserta didik kelas X. Waktu belajar dirumah yang dimanfaatkan oleh peserta didik relatif sedikit karena sebagian besar telah dipergunakan untuk bermain game online, baik dirumah maupun yang tersedia di tempat game center

Kata Kunci : Game Online, Minat belajar
\end{abstract}

\section{PENDAHULUAN}

Pendidikan adalah salah satu wadah yang berisi suatu proses belajar mengajar yang diartikan sebagai salah satu rangkaian suatu interaksi antara pendidik dan para peserta didiknya. Pendidikan juga diartikan sebagai suatu proses pertumbuhan individu yang berlangsung sepanjang hayat. Pendidikan merupakan dasar penting bagi kemajuan suatu bangsa, karena dengan pendidikan sebuah bangsa akan mencapai kemajuan, baik dalam pengembangan sumber daya manusia maupun pengelolaan sumber daya alam. Fungsi pendidikan adalah membimbing peserta didik kearah suatu tujuan yang dinilai lebih tinggi. Pendidikan yang baik adalah suatu usaha yang membawa keberhasilan untuk semua anak didik dalam mencapai tujuannya .

Pendidikan adalah suatu pembelajaran, sedangkan belajar adalah suatu yang merubah tingkah laku dan dari perubahan tersebut akan menghasilkan tingkah laku yang lebih baik. Hasil dari proses belajar yang ditempuh melalui jalur pendidikan dapat dilihat dan diukur. Masalah belajar menggambarkan kualitas pendidikan di negara kita. Secara belajar disekolah relatif sedikit, contohnya masih banyak sekolah yang kurang fasilitas sarana dan prasarana. Faktor disekolah dan dedikasi pendidik terhadap hasil belajar peserta didik, lingkungan keluarga, dan dorongan orang tua merupakan faktor-faktor yang mempengaruhi belajar peserta didik. Tetapi, hal yang lebih penting adalah faktor dalam diri peserta didik itu sendiri, yakni dorongan kuat disertai adanya perasaan, kemauan 
Research and Development Journal Of Education

Vol. 5 No. 2 April 2019

p-ISSN 2406-9744

e-ISSN 2657-1056

keras, dan keinginan yang kuat untuk menungkatkan prestasi belajar, oleh karenanya kita lebih sering mengenalnya dengan istilah minat.

Secara psikologi, minat sangat berpengaruh dalam diri seorang peserta didik dalam rangka mencapai apa yang diinginkan oleh peserta didik itu sendiri. Dengan adanya minat yang kuat peserta didik harus memiliki semangat yang kuat pula supaya apa yang dia diinginkannya bisa terwujud. Oleh karena itu, peneliti menyimpulkan bahwa minat itu adalah suatu sikap atau perasaan suka terhadap sesuatu yang seseorang diinginkannya. Jadi, peserta didik tersebut akan berusaha secara terus menerus demi mendapatkannya dan tidak akan menyerah sampai dia mendapatkan apa yang diinginkannya.

Pada era globalisasi kebudayaan asing sangat berpengaruh pada kebudayaan masyarakat lokal, khususnya pelajar. Contohnya adalah penggunaan internet. Perkembangan internet saat ini semakin pesat dan menarik pengguna dari berbagai kalangan masyarakat. Menurut data pengguna internet di Indonesia diketahui telah mencapai 88,1 juta orang (PUSKAKOM UI, 2015). Besar pertumbuhan internet tidak sebanding dengan dengan besarnya jumlah penduduk Indonesia yang hanya sekitar 252,4 juta jiwa, oleh sebab itu dikatakan bahwa kenaikan pengguna internet di negara ini mencapai 34,9\%. Angka tersebut meningkat cukup banyak bila dibandingkan dengan tahun 2013 dimana penetrasi internet baru mencapai $28,6 \%$.

Internet yang semula dirancang untuk sistem komunikasi militer telah berkembang menjadi penghubung banyak komputer sekaligus kedalam sebuah jaringan (Groothuis : 285, 1977). Jejaring internet tidak hanya bersifat menghubungkan, melainkan juga dapat menjadi perangkap bagi penggunanya. Internet sangatlah menarik karena memuat warna, suara, gerakan, ketidakterbatasan informasi, dan kesegaran respon. Dibanding televisi yang juga mempunyai efek mencandu, internet memliki kelebihan karena sifat yang tidak terbatasnya waktu akses, interaktif, menantang dan sangat variatif. tertariknya seseorang terhadap internet adalah karena adanya kepentingan, minat dan kepribadian individu seperti ketertarikannya pada game online.

David Greenfield seorang pakar psikolog di Amerika, menemukan kira kira 6\% dari pengguna internet khususnya peserta didik mengalami kecanduan. Para peserta didik tersebut memiliki gejala yang sama dengan gejala seseorang 
Research and Development Journal Of Education

Vol. 5 No. 2 April 2019

p-ISSN 2406-9744

e-ISSN 2657-1056

yang kecanduan obat bius yaitu bisa lupa waktu jika sedang berinternet. Kebanyakan para peserta didik yang kecanduan internet ini disebabkan karena mereka mendapat atau menemukan kepuasan yang tidak mereka dapatkan didunia nyata.

Game online adalah sebuah gaya hidup baru bagi beberapa individu pada setiap kalangan umumnya. Pada masa ini warung internet (Warnet) sudah banyak ditemui dikota maupun didesa, warnet memberikan fasilitas adanya game online . Komputer (PC) yang digunakann berbeda dengan komputer biasa, selain lebih mahal komputer (PC) tersebut mempunyai spesifikasi untuk bermain game. Koneksi internet untuk sebuah game online juga harus memadai. Modal untuk membuat sebuah Game Center, yaitu tempat bermain khusus game online adalah cukup besar. Faktanya game center sudah sangat mudah kita jumpai di kota maupun di desa dan keberadaannya menjadi candu atau ketagihan.

Dalam perspektif sosiologi, individu yang menjadikan game online sebagai candu lebih cenderung menjadi egosentris dan individualis. Hal ini membahayakan kehidupan sosial dari individu tersebut, mereka akan menjauh dari lingkungan sekitar dan memungkinkan akan membuat dirinya seperti kaum marjinal yang menggangap kehidupannya ada di dunia maya dan lingkungan sosialnya hanya ada di tempat dia bermain game tersebut. Golongan mereka lebih banyak adalah peserta didik dati tingkat Sekolah Dasar sampai dengan Perguruan Tinggi, dari status ekonomi menengah keatas maupun golongan ekonomi kebawah.

Hal inilah yang menyebabkan kebanyakan dari mereka terperangkap pada aktifitas negatif seperti game online. Kecanduan game online mengakibatkan persoalan dalam minat belajar peserta didik. Peserta didik akan mengalami penurunan minat belajar sehingga mereka akan melalaikan tugas-tugas belajar. Peserta didik juga akan lebih memilih bolos sekolah karena waktunya habisdi game centre.

Paradigma dari suatu perkembangan teknologi adalah untuk membantu dan meningkatkana prestasi belajar baik dalam aspek kognitif maupun aspek psikomotor peserta didik di era globalisasi sekarang ini. kenyataannya perkembangan tekhnologi berupa game online justru membuat arus balik yaitu menurunkan minat belajar mereka. Termasuk Peserta didik Sekolah Menengah 
Research and Development Journal Of Education

Vol. 5 No. 2 April 2019

p-ISSN 2406-9744

e-ISSN 2657-1056

Atas. Dari uraian tersebut diatas, maka penulis dalam penelitian ini mengambil judul Pengaruh Game Online terhadap Minat Belajar Kelas X di MA Al Hidayah Depok.

\section{TINJAUAN PUSTAKA}

\section{Pengertian Minat Belajar}

Pada setiap individu akan lebih cenderung untuk berhubungan dengan sesuatu yang dia anggap bisa memberikan kesenangan dan kebahagiaan. Dan dari perasaan senang itu kemudian timbul suati keinginan untuk memperoleh dan mengembangkan apa yang sudah membuatnya senang dan bahagia. Minat dapat dilihat atau dari rasa suka yang mempunyai kaitan pada suatu hal atau aktivitas tanpa harus disuruh. Artinya, diharuskan ada suatu rasa rela dari seseorang dalam melakukan sesuatu yang disukai. Dengan demikian, timbulnya minat terjadi dari adanya suatu penerimaan dan suatu hubungan antara diri sendiri dengan sesuatu yang berada diluar dirinya. Bila kekuatannya semakin besar hubungan tersebut maka semakin dekat pula minat seseorang.

Adanya minat dalam diri seseorang juga dapat dilihat dari ungkapan atau pernyataan yang ditunjukkan seseorang dalam menyukai sesuatu hal dari pada yang lain. Serta dapat pula diungkapkan melalui aktivitas tertentu. Individu yang memiliki minat terhadap sesuatu akan memberikan perhatian yang cenderung lebih besar terhadap benda tersebut. Misalnya mengoleksi beberapa benda yang memiliki arti tertentu bagi dirinya seperti perangko, boneka, poster dan lain sebagainya.

Slameto (2010: 57) mengatakan bahwa minat merupakan kecenderungan yang selalu tetap untuk memperhatikan dan mengenang kegiatan. Kegiatan yang diminati tersebutnakan diperhatikan terus menerus dengan diiringi rasa senang. Minat mempunyai pengaruh yang sangat besar untuk belajar, apabila materi yang akan dipelajari tidak sesuai dengan minat peserta didik, mereka pasti tidak akan belajar dengan baik. Materi yang menarik minat, lebih mudah dipelajari karena akan menambah dorongan untuk belajar.

Holland (dalam Djali, 2007: 122) berpendapat bahwa minat adalah kecenderungan hati yang tinggi terhadap sesuatu. Minat ini tidak timbul dengan sendirinya, melainkan ada faktor-faktor yang dapat mempengaruhi timbulnya 
Research and Development Journal Of Education

Vol. 5 No. 2 April 2019

p-ISSN 2406-9744

e-ISSN 2657-1056

minat dalam diri seseorang seperti rasa butuh terhadap sesuatu, rasa ingin tahu, dan adanya ketertarikan terhadap suatu hal. Di lain pihak, Syah (2005: 136) mengatakan bahwa secara sederhana, minat (interest) mempuyai arti sebuah kecenderungan serta gairah yang tinggi atau keinginan yang sangat besar terhadap sesuatu. Minat sangat berpengaruh pada kualitas suatu pencapaian belajar atau prestasi belajar peserta didik.

Winkel (2004: 30) berpendapat bahwa minat juga merupakan suatu kecenderungan yang menetap pada suatu subyek untuk merasa tertarik pada suatub bidang/hal tertentu dan merasa senang untuk selalu berkecimpung dalam bidang itu. Berdasarkan definisi tersebut ada sebuah kata "merasa senang" dimana artinya adanya minat dalam diri siswa akan membuat siswa merasa senang ketika memainkan sesuatu, seperti main game. Rasa senang ini dapat berupa rasa puas, rasa gembira, rasa simpati, dan lain sebagainya. Merupakan anggapan yang salah apabila minat sudah dibawa sejak lahir. Minat timbul karena adanya hubungan dengan sesuatu. Minat pada suatu dapat dipelajari dan berpengaruh pada kegiatan belajar selanjutnya dan dapat mempengaruhi penerimaan minat-minat baru. Minat merupakan suatu rasa atau sangat suka dan rasa tertarik pada suatu hal atau aktivitas tanpa harus disuruh. Pada dasarnya minat merupakan penerimaan suatu hubungan diri sendiri dengan sesuatu yang ada diluar diri. Semakin kuat hubungan, maka semakin besar minatnya.

Berdasarkan beberapa pengertian diatas, bisa ditarik kesimpulan minat merupakan kecenderungan hati untuk melakukan suatu hal atau aktivitas tersebut secara terus-menerus dan dilakukan tanpa adanya paksaan dari orang lain, sebaliknya selalu disertai dengan rasa senang.

Ciri - ciri minat pada seseorang antara lain :

1. Minat tumbuh bersama perkembangan fisik dan mental

2. Minat bergantung pada kesiapan belajar

3. Minat bergantung pada kesempatan belajar

4. Perkembangan minat terbatas

5. Minat dipengaruhi oleh budaya

6. Minat berbobot emosional

7. Minat itu egosentrik 
Research and Development Journal Of Education

Vol. 5 No. 2 April 2019

\section{Unsur-Unsur Minat}

Ada beberapa hal yang menyebabkan seseorang dikatakan berminat terhadap sesuatu apabila individu tersebut memiliki beberapa unsur, antara lain :

1. Perhatian

2. Perasaan senang

3. Motif

\section{Faktor Yang Mempengaruhi Minat}

Minat belajar yang tinggi adalah salah satu pendorong keberhasilan belajar.. Ada beberapa faktor yang dapat mempengaruhi minat belajar peserta didik antara lain sebagai berikut :

1. Keinginan belajar seseorang akan semakin tinggi bila disertai dengan minat, baik yang bersifat internal maupun eksternal.

2. Bahan pelajaran dan sikap seorang guru

3. Keluarga

4. Lingkungan

5. Cita-cita

6. Bakat

7. Hobi

8. Media massa

9. Fasilitas

Namun secara garis besar faktor-faktor yang mempengaruhi minat dapat dikelompokkan menjadi dua yaitu bersumber dari diri individu yang bersangkutan maupun yang berasal dari luar individu.

a. Faktor internal

Adapun faktor yang tergolong dalam fakor internal, yaitu :

1. Motif merupakan keadaan dalam diri seseorang yang mendorong individu untuk melakukan aktivitas-aktivitas tertentu guna mencapai tujuan.

2. Sikap adalah adanya kecenderungan dalam subyek untuk menerima, menolak suatu obyek yang berharga baik atau tidak baik.

3. Permainan adalah merupakan suatu permasalahan tenaga psikis yang tertuju pada suatu subyek semakin intensif perhatiannya. 
Research and Development Journal Of Education

Vol. 5 No. 2 April 2019

p-ISSN 2406-9744

e-ISSN 2657-1056

4. Pengalaman yaitu suatu proses pengenalan lingkungan fisik yang nyata baik dalam dirinya sendiri maupun diluar dirinya dengan menggunakan organ-organ indra.

5. Tanggapan adalah banyaknya suatu hal yang tinggal dalam ingatan setelah itu melakukan pengamatan.

6. Persepsi merupakan suatu proses untuk mengingat atau mengidentifikasi sesuatu, biasanya dipakai dalam persepsi adalah rasa, bila benda yang kita ingat atau yang kita identifikasikan adalah obyek yang mempengaruhi oleh persepsi, karena merupakan tanggapan secara langsung terhadap suatu obyek atau rangsangan.

b. Faktor eksternal

Lingkungan bisa juga sangat mempengaruhi minat, lingkungan juga mempunyai peranan yang penting terhadap individu, baik lingkungan fisik yang berhubungan dengan benda konkrit maupun lingkungan fisik yang berhubungan dengan jiwa setiap individu. Lingkungan itu sendiri terdiri atas dua bagian, yakni lingkungan fisik, yaitu berupa alat misalnya keadaan tanah dan lingkungan sosial, yaitu merupakan lingkungan masyarakat dimana lingkungan ini adanya interaksi individu satu dengan yang lain. Keadaan masyarakat akan memberikan pengaruh tertentu kepada individu.

\section{Metode Pengukuran Minat}

Ada beberapa metode yang dapat digunakan untuk mengadakan pengukuran minat, yaitu:

1) Observasi

Pengukuran minat dengan menggunakan metode observasi mempunyai suatu keuntungan karena dapat mengamati minat anak-anak dalam kondisi wajar, jika tidak dibuat-buat. Observasi dapat dilakukan dalam setiap situasi, baik dalam kelas maupun diluar kelas. Pencatat hasil observasi dapat dilakukan observasi berlangsung. Observasi dilakukan terhadap bebrapa orang anak berdasarkan data yang telah terkumpulkan sebelumnya.

2) Interview

Metode interview baik digunakan untuk mengukur minat anak, gemar memperbincangkan hobinya dan aktivitas lain yang menarik hatinya. Pelaksana interview sebaiknya dilakukan dalam situasi yang tidak formal, sehingga lebih 
Research and Development Journal Of Education

Vol. 5 No. 2 April 2019

p-ISSN 2406-9744

e-ISSN 2657-1056

santai dan bebas. Misalnya pada waktu istirahat diluar jam pelajaran, dengan kunjungan kerumah dan lain-lain. Penggunaan metode interview memerlukan waktu yang cukup lama untuk mengumpulkan data. Dengan metode interview peneliti harus memikirkan tentang pelaksanaannya, karena menyebarkan angket kepada responden dan menghendaki jawaban tertulis, lebih mudah jika dibandingkan dengan mengorek jawaban responden dengan bertatap muka.

\section{3) Kuisioner}

Sebagian besar penelitian dilakukan dengan menggunakan metode kuisioner sebagai pengumpulan data. Kuisioner atau angket memang mempunyai banyak kebaikan sebagai instrumen pengumpul data. Penggunaan metode kuisioner akan menjadi lebih baik asal cara dan pengadaannya mengikuti persyaratan yang telah digariskan dalam penelitian.

\section{Pengertian Game Online}

Game adalah aktivitas yang dilakukan untuk fun atau menyenangkan yang memiliki aturan sehingga ada yang menang dan ada yang kalah (Kamus Macmillan, 2009-2011). Selain itu, game juga mempunyai arti sebuah kontes, baik fisik ataupun mental, menurut aturan tertentu, untuk hiburan, rekreasi, atau untuk menang taruhan. Direktur Indonesia Gamer, eddy Liem sebuah pencinta games di Indonesia, mengatakan game online adalah sebuah permainan yang dimainkan secara online dengan menggunakan internet, bisa dimainkan dengan menggunakan PC (personal computer) atau konsul game biasa seperti PS2, XBox.

Dalam kamus Wikipedia, game online dikatagorikan permainan yang mengacu pada sejenis games yang dimainkan melalui jaringan komputer, umumnya juga menggunakan jaringan internet. Internet games biasanya dimainkan oleh beberapa orang pemain dalam waktu yang bersamaan dimana satu sama lain bisa tidak mengenal. Game online merupakan salah satu bentuk teknologi yang hanya bisa diakses menggunakan jaringan komputer.

\section{Sejarah dan Perkembangan Game Online}

Perkembangan game online tidak terlepas dari perkembangan teknologi komputer dan jaringannya. Pesatnya jaringan komputer yang awalnya hanya berskala kecil (small local network) dan kemudian menjadi internet sampai 
Research and Development Journal Of Education

Vol. 5 No. 2 April 2019

p-ISSN 2406-9744

e-ISSN 2657-1056

sekarang. Tahun 1969 pada awal munculnya, komputer untukm nermain game hanya bisa dipakai untuk 2 orang saja. Seiring perkembangannya kemudian muncullah komputer yang mempunyai kemampuan time-sharing sehingga orang yang memainkan game tersebut bisa lebih banyak dan tidak harus ada dalam satu ruangan yang sama (Multiplayer Games).

Jaringan komputer yang berbasis paket (packet based computer networking) jaringan komputer yang juga tidak hanya sebatas LAN (Local Area Network) saja tetapi sudah mencakup WAN (Wide Area Network) dan menjadi internet muncul pada tahun 1970. Pada awalnya Game online yang muncul kebanyakan gamegame berupa simulasi perang atau pesawat militer yang kemudian dikomersialkan. Game-game tersebut kemudian menjadi inspirasi munculnya game-game yang lain dan lebih berkembang.

Aradhana Grupta, mengatakan pada tahun 1995, peraturan - peraturan dalam industri game yang sudah diperkenalkan sebelumnya telah dibatalkan oleh NSFNET (National Science Foundation Network). Ketercapaian pemain dalam online gaming serta perkembangannya melaju dengan begitu pesat setelah adanya pembatalan tersebut.

\section{Jenis-Jenis Game Online}

Game online dikelompokkan menjadi dua jenis, yang pertama yaitu web based game dan yang kedua text based game. Web based games merupakan aplikasi yang diletakkan pada server dan setiap pemain hanya menggunakan akses internet dan browser untuk dapat mengakses games tersebut. Untuk memainkannya tidak perlu menginstall atau patch untuk memainkan gamenya. Kemudian berkembang, dengan adanya beberapa fitur yang harus di download untuk memainkan sebagian game, contohnya seperti Java Player, Flash Player, maupun Shockwave Player, yang sangat diperlukan untuk merubah tampilan grafis game tersebut. Game seperti itu tidak lagi membutuhkan spesifikasi komputer yang canggih, tidak lag dan memerlukan bandwith yang besar. Sebagian besar web based game bisa dimainkan secara gratis. Bila memerlukan fitur - fitur tambahan dan untuk mempercepat perkembangan account nya baru perlu melakukan pembayaran. 
Research and Development Journal Of Education

Vol. 5 No. 2 April 2019

p-ISSN 2406-9744

e-ISSN 2657-1056

Text based game sebenarnya sudah lebih dahulu ada dari web based games,yaitu pada saat sebagian komputer masih berspefikasi rendah dan belum bisa atau susah untuk memainkan game-game dengan grafis canggih, biasanya pemain hanya berinteraksi dengan teks sedikit dan tanpa gambar. Text based games kemudian hampir tidak diminati lagi oleh para pemain game, tetapi sekarang ini, mulai marak text based games yang beredar dan yang lebih kita kenal sebagai web based game. pastinya dengan format yang lebih modern, grafisnya juga lebih banyak dan lebih cantik, serta menggunakan jaringan dan koneksi internet dari developer game yang makin kreatif.

\section{Dampak Game Online}

Masyarakat kini lebih meyakini bahwa game online lebih banyak memberikan pengaruh negatif bagi pemainnya. Karena sebagian besar game berupa permainan yang adiktif dan biasanya berisi tentang kekerasan pertempuran dan perkelahian. Sebagian besar orang tua juga media berpikir dan lebih percaya permainan tersebut dapat merusak otak anak karena lebih banyak menampilkan kekerasan di antara mereka (pande, A Mahreni 2015). Tapi, tidak sedikit pula psikolog, pakar anak, dan para ilmuwan mempercayai bahwa permainan itui sebenarnya bisa mempunyai manfaat bagi perkembangan dan pertumbuhan anak. Jadi, dapat disimpulkan terdapat dampak positif dan negatif pada game online bagi para pemainnya.

Berdasarkan pada pendahuluan dampak game online, ternyata juga memiliki dampak negatif dalam permainan game online. Hampir $89 \%$ dari permainan mengandung beberapa konten tentang kekerasan (Children Now, 2001), dan mayoritas dari permainan itu juga termasuk konten tentang kekerasan terhadap karakter permainan lainnya yang akan menyebabkan luka berat atau kematian (Children Now, 2001; Dietz, 1998; Dill, Gentile, Richter, \& Dill, 2001). Konten yang berlandaskan kekerasan inilah yang menimbulkan beberapa dampak negatif. Antaranya:

a. Game yang berlatar belakang atau kontennya bersifat kekerasan memicu anakanak untuk meningkatkan pikiran agresif, perasaan, dan perilaku, dan penurunan prososial.

b. Terlalu banyak bermain game membuat anak terisolasi dari dunia luar. 
Research and Development Journal Of Education

Vol. 5 No. 2 April 2019

p-ISSN 2406-9744

e-ISSN 2657-1056

c. Beberapa game mengajar nilai-nilai yang tidak bermoral.

d. Game dapat membingungkan antara realitas dan fantasi bagi pemainnya.

e. Prestasi akademik akan menurun.

\section{Kecanduan Game Online}

Kecanduan bisa diartikan "An activity or substance we repeatedly crave to experience, and for which we are willing to pay a price (or negative consequences)" yang maksudnya adalah suatu aktivitas atau substansi yang dilakukan secara beulang-ulang dan dapat menimbulkan dampak negatif. Contoh kecanduan bisa bermacam-macam. Yaitu kecanduang yang bisa timbul akibat zat atau aktivitas tertentu, misalnya judi, overspending, shoplifting serta aktivitas seksual. Salah satu perilaku yang termasuk di dalamnya adalah ketergantungan pada game. Ada dua jenis kecanduan, pertama yaitu adiksi fisikal seperti kecanduan mengkonsumsi alkohol atau kokaine, dan kedua yaitu adiksi nonfisikal seperti kecanduan terhadap game online secara berlebihan yang lebih dikenal dengan istilah Game Addiction. Maksudnya adalah seorang anak lebih ingin bermain game karena seakan-akan tidak ada hal yang ingin dikerjakannya selain bermain game, dan seolah-olah game tersebut adalah hidupnya. Bagi perkembangan seorang anak hal ini sangat riskan mengingat perjalanan hidupnya yang masih panjang.

Menurut psikiater orang yang kecanduan game akan lebih sulit ditangani dan di sembuhkan daripada pasien yang kecanduan pornografi. Karena, pecandu game akan malu untuk menceritakan 'aibnya'. Bahkan ada seorang psikiater yang sudah sangat ahli menangani pasien kecanduan game mengatakan ada beberapa pasiennya lebih merasa malu gara-gara kecanduan game World of Warcraft daripada melihat pornografi. Nicholas Yee (2002:309) menyebutkan indikator dari individu yang mengalami kecanduan terhadap games, memiliki sebagian atau semua ciri-ciri berikut :

1. Cemas, frustasi dan marah ketika tidak melakukan permainan.

2. Perasaan bersalah ketika bermain.

3. Terus bermain meskipun sudah tidak menikmati lagi.

4. Teman atau keluarga mulai berpendapat ada yang tidak beres dengan individu karena game.

5. Masalah dalam kehidupan sosial. 
Research and Development Journal Of Education

Vol. 5 No. 2 April 2019

p-ISSN 2406-9744

e-ISSN 2657-1056

6. Masalah dalam hal finansial atau hubungan dengan orang lain.

Kecanduan internet games merupakan jenis kecanduan psikologis seperti halnya Internet Addiction Disorder (IAD). Ivan Goldberg (1996) menyebutkan bahwa penggunaan internet yang maladaptif yang mengarah pada kerusakan atau distress yang signifikan secara klimis dan terwujud melalui tiga atau lebih dari hal-hal berikut, yang terjadi kapan saja dalam waktu 12 bulan yang sama :

1. Toleransi

2. Penarikan diri

3. Internet sering atau lebih sering digunakan lebih lama dari yang direncanakan

4. Usaha yang gagal dalam mengendalikan penggunaan internet

5. Menghabiskan banyak waktu dalam kegiatan yang berhubungan dengan penggunaan internet

6. Kegiatan-kegiatan penting seperti bidang sosial, pekerjaan, atau rekreasional dihentikan atau dikurangi karena penggunaan internet

7. Penggunaan internet tetap dilakukan walaupun mengetahui adanya masalahmasalah fisik, sosial, pekerjaa, atau psikologis yang kerap timbul dan kemungkinan besar disebabkan penggunaan internet.

\section{METODE}

Metode penelitian yang digunakan penulis adalah pendekatan kuantitatif dengan jenis penelitian korelasional atau saling mempengaruhi. Dengan pendekatan korelasionalitas dapat dilihat pengaruh antara satu variabel bebas (game online) yang mempengaruhi simbol $\mathrm{X}$, dan variabel terikat (minat belajar) sebagai yang dipengaruhi diberi simbol Y.

\section{Populasi dan Sampling}

Populasi target dalam penelitian ini adalah seluruh peserta didik di MA Al Hidayah Depok tahun ajaran 2017/2018. Adapun populasi terjangkau atau sampel yang digunakan dalam penelitian ini adalah peserta didik kelas $\mathrm{X}$ yang berjumlah 45 peserta didik dalam satu kelas.

\section{HASIL DAN PEMBAHASAN}

\section{Hubungan Game Online Dengan Minat Belajar}

Dari hasil penelitian menunjukkan adanya korelasi yang berkaitan tinggi dan positif $(r=0,611)$ antara game online terhadap minat belajar peserta didik. 
Research and Development Journal Of Education

Vol. 5 No. 2 April 2019

p-ISSN 2406-9744

e-ISSN 2657-1056

Jika pengaruh game online meningkat dikalangan peserta didik, maka minat belajar akan menurun. Sebaliknya jika pengaruh game online menurun maka maka minat belajar peserta didik akan meningkat.

\section{Besarnya Kontribusi Terhadap Minat Belajar}

Berdasarkan hasil penelitian tersebut menunjukkan bahwa besarnya kontribusi pengaruh game online terhadap minat belajar peserta didik adalah $37,33 \%$ sedangkan sisanya $62,67 \%$ dipengaruhi oleh faktor lain.

\section{Minat Belajar Peserta Didik}

Dari hasil perhitungan diperoleh nilai koefisien $a=32,31$ satuan dan $b-$ 0,59. Dari nilai-nilai koefisien refresi yang diperoleh tersebut maka dapat ditentukan persamaan regresinya yaitu $\mathrm{Y}=32,31+0,59 \mathrm{X}$. Dari persamaan tersebut dapat diketahui bahwa konstanta (a) sebesar 32,31. Hal ini dapat diartikan bahwa tanpa adanya faktor game online yang tersebar, minat belajar sudah terbentuk secara nyata sebesar 32,31 satuan, kemudian koefisien regresi (b) sebesar 0,59 artinya jika minat belajar naik 1 skor maka ketertarikan akan game online akan menurun sebesar 0,59, demikian pula sebaliknya.

\section{Pengaruh Game Online Terhadap Minat Belajar Peserta Didik Kelas X}

Berdasarkan hasil penelitian menunjukkan bahwa koefisien korelasi yang didapat sebesar 0,611. Hal ini membuktikan bahwa terdapat pengaruh negatif antara game online terhadap minat belajar peserta didik. Kemudian pada uji hipotesis penulis menghasilkan $t_{\text {hitung }}$ sebesar 5,060 dan $t_{\text {tabel }}$ sebesar 1,681 dengan tingkat kesalahan $a=0,05$. Artinya terdapat pengaruh yang signifikan antara game online dengan minat belajar peserta didik kelas X di MA Al Hidayah Depok Tahun Ajaran 2017/2018.

\section{SIMPULAN}

\section{Simpulan}

Berdasarkan hasil analisis data dan pembahasan yang telah diuraikan, bahwa game online berpengaruh positif dan signifikan terhadap minat belajar peserta didik di MA Al hidayah Depok Tahun Ajaran 2017/2018. Hal ini dibuktikan dari hasil perhitungan uji korelasi variabel $\mathrm{x}$ dan y yang berkaitan tinggi dan positif $(r=0,611)$ antara game online terhadap minat belajar peserta didik. Jika pengaruh game online meningkat dikalangan peserta didik, maka minat 
Research and Development Journal Of Education

Vol. 5 No. 2 April 2019

p-ISSN 2406-9744

e-ISSN 2657-1056

belajar akan menurun. Begitu juga sebaliknya. Berdasarkan hasil penelitian koefisien determinasi, kontribusi game online dengan minat belajar peserta didik sebesar $37,33 \%$, sedangkan sisanya $62,67 \%$ dipengaruhi oleh faktor lain seperti halnya faktor lingkungan sekitar, faktor individu, faktor keluarga, dan lain sebagainya. Dari persamaan hasil analisa regresi sederhana yakin $\mathrm{Y}=32,31+$ 0,59X, maka dapat dilihat bahwa nilai a(konstanta) sebesar 32,31 satuan. Nilai ini dapat diartikan bahwa pada saat faktor game online sama dengan nol, maka faktor minat belajar yang dapat dibentuk adalah 32,31 satuan. Hal ini dapat diartikan bahwa tanpa adanya faktor game online, minat belajar bisa terbentuk secara nyata sebesar 32,31 satuan.

\section{DAFTAR PUSTAKA}

Adams, E. \& Rolling, A (2010) Fundamentals og Game Online Design (2 $2^{\text {nd }}$ es) B,CA. Barkeley CA - New Riders.

Anonim, (2012). Internet usage and statistics. Internet world stat. March 25, 2012. http://www.internetworldstats.com/asia.htm.

Imanuel, N. (2009). Gambaran profil kepribadian pada remaja yang kecanduan game online dan yang tidak kecanduan game online (Skripsi). Depok: Fakultas Psikologi UI.

Jessica, M. (1999). History of game online. May 30, 2012. http://tharsisgate.org/articles/imaginary/HISTOR 3.HTM.

Kusumadewi, T. (2009). Hubungan kecanduan game online dengan perilaku sosial pada remaja (Skripsi). Depok: Fakultas Psikologi UI.

Lee, Eun Jin. (2011). Acase study of internet game addiction. Journal of Addiction Nursing, 22, 208-213.

Meiriyati, E. (2011). Pengaruh game online terhadap minat belajar (Skripsi). Lampung.

Pande A Mahrani (2015) Hubungan Kecanduan Game Online dengan Prestasi Belajar Siswa SMP Negri 1 Kuta. Jurnal Psikologi Udayana, Vol 2 No 2. Hlm 165-166.

Samuel Henry ( 2010 ) Cerdas dengan Game. Jakarta: PT Gramedia Pustaka.

Slameto ( 2010 ) Belajar dan Faktor - Faktor yang Mempengaruhinya. Jakarta: Rineka Cipta. 